\title{
LORD DENNING, MAGNA CARTA AND MAGNANIMITY
}

\author{
Simon Lee
}

Lord Denning's assessment of Magna Carta at its 750th anniversary has stood the test of half a century: "the greatest constitutional document of all times - the foundation of the freedom of the individual against the arbitrary authority of the despot". ${ }^{1}$ His longer, but still succinct, article for The Times for the same anniversary has not been bettered. ${ }^{2}$ Yet at the time of Magna Carta's $800^{\text {th }}$ anniversary we have lost sight of two other works of Lord Denning which could make a distinctive contribution to our current constitutional debates. Whereas Lord Neuberger has linked the real Magna Carta to the fictitious Holy Grail in an entertaining lecture ${ }^{3}$ on law and myth, for legal scholars the Holy Grail is a long lost text or case. An earlier essay ${ }^{4}$ identified the links between the opening clause of Magna Carta 1215 and s 13 of the Human Rights Act 1998 as worthy of rediscovery. This article presents two further candidates: a neglected lecture on Borrowing from Scotland ${ }^{5}$ by Lord Denning in 1961 and a neglected Court of Appeal decision in 1975 applying Magna Carta, in which Lord Denning presided as Master of the Rolls, $R v$ Secretary of State for the Home Office, ex $p$ Phansopkar. ${ }^{6}$ Between them, they can

\footnotetext{
Fellow of St Edmund's College, Cambridge, Emeritus Professor of Jurisprudence, Queen's University Belfast, and Visiting Professor of Law, University of Buckingham. With thanks to James Lee, James Slater, the Editor and anonymous reviewers.

${ }^{1}$ Lord Denning, quoted by successors as Master of the Rolls, Lord Bingham and Lord Dyson, the latter in Robin Griffith-Jones \& Mark Hill (eds) Magna Carta, Religion and the Rule of Law (Cambridge University Press 2015).

2 Lord Denning, reprinted in The Family Story (Hamlyn, London 1982) 229.

${ }^{3}$ Lord Neuberger, Magna Carta and the Holy Grail, Lincoln's Inn, 12 May 2015, https://www.supremecourt.uk/docs/speech-150512.pdf

${ }^{4}$ Lee, 'The Cardinal Rule of Religion and the Rule of Law' in Robin GriffithJones and Mark Hill QC (eds), Magna Carta, Religion and the Rule of Law (Cambridge University Press 2015) 314-333.

5 Lord Denning, Borrowing from Scotland, 26 ${ }^{\text {th }}$ David Murray Foundation Lecture, University of Glasgow, 5 May 1961, printed by Jackson, Son \& Co, printers to the University, 1963.

${ }^{6} R$ v Home Secretary, ex p Phansopkar (1976) 1 QB 606.
} 
offer refreshing insights into contemporary constitutional controversies.

The main focus here, after drawing attention to the lecture on Borrowing from Scotland, is the Phansopkar case's use of Magna Carta. It is instructive to see how Magna Carta has been used in practice, between its $750^{\text {th }}$ and $800^{\text {th }}$ anniversaries and well ahead of the Human Rights Act 1998. It is also salutary to consider some of those involved in the case, their earlier lives and what happened next. Finally, and briefly, I attempt to link these two seemingly disparate parts of Lord Denning's legacy. There is no mention of Magna Carta in the lecture and no mention of Scotland in the Magna Carta case (or in Magna Carta itself because it was, of course, a foreign country at the time) but forging connections between them is a way of drawing lessons for our wider constitutional controversies.

In 2015, the $800^{\text {th }}$ anniversary of Magna Carta coincides with a new Conservative government in Westminster pledging to "control immigration" and proposing three significant constitutional changes which were in its manifesto: English votes for English laws, in the aftermath of the 2014 referendum rejecting independence for Scotland; a second referendum on membership of the European Union, the first having been in 1975; and a British Bill of Rights to replace the Human Rights Act $1998 .^{7}$ The last of these is already proving problematic and has been delayed, with no commitment on timing in the Queen's Speech. ${ }^{8}$ One common theme is the desirability, or undesirability, of external influences on the legal system of England and Wales, whether from Scotland or Brussels or Luxembourg or Strasbourg. Through various misunderstandings, the different concerns have been conflated into a distrust of "European" judges or other law-makers from outside this legal system. Supporters of the European Convention and its incorporation have not helped. The 1997-2001 Labour government promoted the Human Rights Act under the slogan Bringing Rights Home and then Rights

\footnotetext{
${ }^{7}$ https://www.conservatives.com/Manifesto.

${ }^{8}$ Contrast the detail in the Queen's Speech of the first two with the third:

My Government will bring forward changes to the Standing Orders of the House of Commons. These changes will create fairer procedures to ensure that decisions affecting England, or England and Wales, can be taken only with the consent of the majority of Members of Parliament representing constituencies in those parts of our United Kingdom. My Government will renegotiate the United Kingdom's relationship with the European Union and pursue reform of the European Union for the benefit of all Member States. Alongside this, early legislation will be introduced to provide for an in-out referendum on membership of the European Union before the end of 2017 [EU Referendum Bill]... My Government will bring forward proposals for a British Bill of Rights.
} 
Brought Home) as if it were a good thing for rights to be "at home", as if rights were not at home from 1215 and as if rights were now not to be resolved on the Continent. Now the Conservative government is trying both to "scrap" the Human Rights Act and to rely on much the same argument (note the title of a think tank report, Rights Brought Back Home $^{9}$ ) that we should bring rights home into a British Bill of Rights. Yet the erstwhile supporters of that very process have become so attached to the Human Rights Act 1998 that they are now vehemently against whatever it is that the government thinks it will achieve for (or against) human rights.

Whether or not the past can be deemed a foreign country ${ }^{10}$ for these purposes, it is similarly instructive to question whether there is and should be a place in the contemporary constitution for Magna Carta, not just as a part of what Walter Bagehot called the "dignified" constitution but also as a working part of the "efficient" constitution. Bagehot did not dwell on Magna Carta in his own book on The English Constitution. ${ }^{11}$ Neither did RFV Heuston mention Magna Carta in his Essays on Constitutional Law. ${ }^{12}$ Leo Amery's Thoughts on the Constitution ${ }^{13}$ did not involve many thoughts on Magna Carta, merely passing mentions. Will Magna Carta be forgotten once the $800^{\text {th }}$ anniversary celebrations are over, only to languish until its $900^{\text {th }}$ and $1000^{\text {th }}$ anniversaries? Or can its renewed application, whether in its own right or as part of a new British Bill of Rights, be a fitting legacy from the mass of lectures, exhibitions and other events this year?

Compared to Bagehot's dignified language about the dignified constitution, Lord Sumption, an historian turned lawyer and now a Supreme Court Justice, has been blunt about over-exuberant celebrations of Magna Carta by lawyers in the run-up to the $800^{\text {th }}$ anniversary. ${ }^{14} \mathrm{He}$ dismisses pious praise of Magna Carta as "high-minded tosh" and is scathing about relying for the Rule of Law on rich barons: "Do we need to

\footnotetext{
${ }^{9}$ See also the foreword by Lord Hoffmann to a report for the independent think tank Policy Exchange http://conservativehome.blogs.com/files/px-bringingrights-back-home.pdf

${ }^{10}$ LP Hartley, The Go-Between (Penguin 1953): the opening sentence reads: 'The past is a foreign country; they do things differently there.'

${ }^{11}$ Walter Bagehot, The English Constitution (Oxford 2001).

12 RFV Heuston, Essays in Constitutional Law (London Stevens and Sons Ltd 1961).

${ }^{13}$ Leo Amery, Thoughts on the Constitution (OUP 1947).

${ }^{14}$ Lord Sumption, 'Magna Carta Then and Now', address to the Friends of the British Library, 9 March 2015, https://www.supremecourt.uk/docs/speech150309.pdf
} 
derive our belief in democracy and the rule of law from a group of muscular conservative millionaires from the north of England, who thought in French, knew no Latin or English, and died more than three quarters of a millennium ago? I rather hope not." This could be described as a bit rich from someone whose own robust approach could itself count as "muscular"" and "conservative" been widely reported to have made him a millionaire, ${ }^{17}$ albeit not one from the north.

Lord Sumption could not possibly have been criticising Lord Neuberger's lecture ${ }^{18}$ on Magna Carta and the Holy Grail because that came later and indeed praises Lord Sumption's analysis. The President of the Supreme Court, Lord Neuberger, tells us he was "somewhat taken aback" to be told, by his judicial assistant, ${ }^{19}$ that the rapper Jay $\mathrm{Z}$ has an album with Magna Carta in its title (Magna Carta Holy Grail). He confessed to not understanding why the album title referred to Magna Carta: "Listening to the music, digesting the lyrics, and reading its Wikipedia entry leave me little wiser as to why the album has the title that it does, but I suppose that when it comes to subtle allusions, rap-singers may have it over judges." Quite so. This could be a metaphor for our times, that whilst judges know who The Beatles were, ${ }^{20}$ they think they

${ }^{15}$ On his muscular approach as a QC, see various accounts of his actions when representing the Foreign Office, writing to Lord Neuberger to press for a paragraph in a judgment to be redacted, eg

http://www.theguardian.com/world/2010/feb/10/binyam-mohamed-tortureannotated-letter.

${ }^{16}$ On his conservative approach to judging, see Sir Stephen Sedley's scathing critique of Lord Sumption's critique of Sir Stephen Sedley and other more radical, activist judges, 'Judicial Politics', London Review of Books 23 February 2012, http://www.lrb.co.uk/v34/n04/stephen-sedley/judicial-politics.

17 The Daily Telegraph estimated his earnings at the Bar as $£ 2 \mathrm{~m}$ pa http://www.telegraph.co.uk/news/uknews/law-and-order/7207378/Profile-of-QCat-centre-of-Binyam-case.html, The Daily Mail at $£ 3 \mathrm{~m}$ pa

http://www.dailymail.co.uk/news/article-1263225/Binyam-Mohamed-legaltorture-case-cost-taxpayers-750-000.html and The Sunday Times at $£ 8 \mathrm{~m}$ for one case. www.thesundaytimes.co.uk/sto/news/uk_news/Society/article1121765.ece.

${ }^{18}$ Lord Neuberger (n 3).

${ }^{19}$ Hugh Comber (n 3).

${ }^{20}$ The legal journalist Marcel Berlins doubts that any judge really asked this, or did not know, even if the same newspaper attributes it in its obituary columns to Judge James Pickles, without citing a particular occasion. See http://www.theguardian.com/commentisfree/2007/may/21/uk.law http://www.theguardian.com/law/2010/dec/22/judge-james-pickles-dies 
can also understand modern music (or law) by listening and staring at accompanying texts without appreciating context, subtext and underlying culture. Lord Neuberger gives no hint of having grasped that Jay Z's real surname is Carter and that the music millionaire formerly known as Shawn Carter was having fun in praise of himself (Great Carter, get it?). ${ }^{21}$

More seriously, there is something lacking in Lord Neuberger's approach in his lecture to assessing the importance of Magna Carta in modern courts. Despite having been one of Lord Denning's successors as Master of the Rolls, Lord Neuberger ignored the Court of Appeal in considering the impact of the 1215 Charter by just searching the on-line database Bailii for House of Lords or Supreme Court decisions which mentioned Magna Carta in the last 120 years, finding only ten. ${ }^{22}$ He thus missed the case which I have in mind as a way of commemorating Magna Carta and which merits consideration of how it might be applied in years to come, $R v$ Secretary of State for the Home Office, ex $p$ Phansopkar from 1975. So far Bailii is comprehensive below our highest court only from 1996, only featuring earlier Court of Appeal judgments if attention is drawn to a landmark decision. Phansopkar deserves that accolade.

The Supreme Court Justices lecturing on Magna Carta ${ }^{23}$ have not mentioned this Phansopkar case. More generally, they and others have been lecturing on the wider constitution ${ }^{24}$ and even the Union ${ }^{25}$ without addressing the lecture by Lord Denning. The danger of anyone offering an alternative view on Magna Carta is, as Lord Sumption claimed, that "It is impossible to say anything new about Magna Carta unless it is mad." 26 Even then, he suspects someone else will have said it. I have already offered a different perspective on Magna Carta. Although dismissed as peripheral, s 13 of the Human Rights Act 1998 is an extended version of Magna Carta's first clause on freedom of religion. ${ }^{27}$ Section 13 is now being mentioned as significant in the government's deliberations on its manifesto commitment to replace the Human Rights Act with a British

\footnotetext{
${ }^{21}$ Lee (n 4) 320.

${ }^{22}$ Neuberger (n 3).

${ }^{23}$ Neuberger (n 3) and Sumption (n 14).

${ }^{24}$ Neuberger, Hale https://www.supremecourt.uk/docs/speech-150205.pdf Reed http://www.innertemple.org.uk/downloads/members/lectures_2013/lecture_reed_ 2013.pdf

${ }^{25}$ Most egregiously, Lord Sumption, even when giving a lecture to the Denning Society on This Disunited Kingdom: England, Ireland and Scotland, 5 November 2013, https://www.supremecourt.uk/docs/speech-131105.pdf

${ }^{26}$ Sumption (n 14).
} 
Bill of Rights. It only takes the same will to rehabilitate both the idea of Borrowing from Scotland and the Court of Appeal's example of using Magna Carta.

\section{THEY COME OVER HERE ... (PART ONE)}

Fear, dislike and distrust of the other is not confined to contemporary debates on immigration or Unions. A disrespectful phrase has become a sinister by-word for prejudice: "They come over here, taking our ..." (jobs, houses, and so on). So of whom was it said, and when was it said, that, "They have pounced upon us, like swarms of locusts, into every quarter and every scene of life ... And when there is anything to be got, you may be sure to find a number...conven'd, like Hounds over a Carrion: or flies in the shambles"? ${ }^{28}$

Lord Denning had a more flowing way of talking about the influence of European law as an incoming tide ${ }^{29}$ but those who think of him as a "Little Englander" who might have made this remark in the last century are wide of the mark. The people being attacked by the English press in this instance were the Scots in 1746. In particular, the rumour was that a Scot called William Murray was going to be made a judge in England. Lord Denning, in an outstanding but neglected lecture, does us a service by reporting this xenophobia and the lawyer's response to his critics, which was to point out anonymously that if they did not like the Scots, then the easy remedy would be to repeal the Act of Union of 1707. This lawyer from Scotland did indeed become a judge and then, ten years later, William Murray became the Lord Chief Justice of England, taking the title Lord Mansfield. For 32 years, he held that high office with the utmost distinction. He is especially praised on either side of the Atlantic for the release of a slave in the Somersett ${ }^{30}$ case and for recognising the right to free speech in the John Wilkes case. ${ }^{31}$ Despite not mentioning Magna Carta in either, Lord Mansfield has come to represent the spirit of Magna Carta as the archetypal English judge, fiercely independent, championing the cause of freedom under the law. Yet he was born at Scone and in many ways, even though he left Scotland at the age of 14, he applied Scottish thinking and law in his English setting. This is explained in the substance of Lord Denning's lecture. He records Lord Mansfield's admiration of Scottish writers on law in Stair, Mackenzie and Craig. Then

\footnotetext{
${ }^{28}$ Denning (n 5) 7.

${ }^{29}$ Bulmer v Bollinger [1974] Ch 401.

${ }^{30}$ Somersett's case (1771) 20 State Trials 1-82, quoted at 16.

${ }^{31} R v$ Wilkes (1768) 98 ER 327, 347.
} 
he pays tribute to Lord Mansfield's following of Scottish law in commercial matters, focusing on principles. ${ }^{32}$ Next he singles out for praise Lord Mansfield's development of the action for unjust enrichment, aligning law and equity, following Roman Law and Scots law. ${ }^{33}$ Finally, Lord Denning praises Lord Mansfield for doing "his best to bring the English law into line with Scots law" ${ }^{34}$ in contract, whether or not there was consideration. It will not have escaped those familiar with Lord Denning's jurisprudence that Lord Mansfield is being lauded in all these respects for having anticipated how Lord Denning would have liked the law to have developed. Where Lord Mansfield was thwarted, as with contract, Lord Denning would "very much like to see the English take a leaf out of Scotland's book". ${ }^{35}$ And where Lord Mansfield was criticized, as by Lord Redesdale who thought "Lord Mansfield had in his mind prejudices derived from his familiarity with the Scots law", ${ }^{36}$ Lord Denning believes that "time has shown that these criticisms were not merited". 37

Admittedly, there is a difference between judicial decision-making (including some development of the law) and elected law-making. Nevertheless, at least a judicious judicial Scottish vote for English laws can be wholly admirable.

Lord Denning might not be the most obvious candidate as a cheerleader for Scottish judges in the English legal system. If we continue to ignore the lecture, of course, that assumption will prevail. But why did Lord Denning choose this topic at that time? Presumably, he was asked to give a prestigious lecture and chose a theme which would have appealed to his audience in Scotland. It also played to his own interest in great judges and history. Above all, however, Lord Denning saw himself as an outsider to the English legal establishment, a grammar school ${ }^{38}$ boy with a distinctive Hampshire burr of an accent, and was well disposed to others of similar talent who brought something different to our courts. Lord Mansfield came from a much more privileged background but he

\footnotetext{
32 Denning (n 5) 10.

${ }^{33}$ Eg Moses $v$ Macfarlen (1760) 2 Burrow at 1012, cited by Lord Denning ( $\mathrm{n}$ ) 12.

${ }^{34}$ Denning (n 5) 13.

${ }^{35}$ Ibid 15 .

${ }^{36}$ Ibid 12 .

${ }^{37}$ Ibid 3.

38 See Lee, 'Lord Denning, Margaret Thatcher, Law and Society' (2013) 25 The Denning Law Journal 159, 160: 'Both rose to high office from humble beginnings above family shops'.
} 
succeeded as an outsider to the extent that he was from Scotland and had endured that unwelcoming press on rumours of his judicial appointment.

The next great "English" legal figure admired by Lord Denning in this lecture was Thomas Erskine, another Scot, who was born in Edinburgh in 1750. He is renowned for his emphasis on the independence of the Bar and for his defence of freedom of speech. ${ }^{39}$ A powerful advocate, he became Lord Chancellor. Then came John Campbell, born in 1781 in Fifeshire, who became Attorney-General, Lord Chief Justice and Lord Chancellor. On his appointment as Lord Chancellor, he recommended Colin Blackburn to replace him on the Queen's Bench. Blackburn was born in 1813 in Dunbartonshire Lord Denning notes that The Times was unimpressed: "Who is Mr Colin Blackburn?" The only explanation entertained by The Times for this "freak" appointment was that he was another "Scotchman". ${ }^{40}$ According to Lord Denning, however, "Colin Blackburn was the greatest lawyer of the nineteenth century". Many a student even in the twenty-first century knows, or at least knows of, his judgment in Rylands $v$ Fletcher. ${ }^{42}$

Lord Denning continues in this vein when it comes to the twentieth century, full of praise for the influence on English law of one Scottish judge after another. Scottish Lord Chancellors of the twentieth century ran from Lord Loreburn through Viscount Kilmuir at the time of Lord Denning's lecture (and on to Lord Mackay and Lord Irvine later in the century). Two of the judges in Donoghue $v$ Stevenson were Scottish, Lords Thankerton and Macmillan, ${ }^{43}$ both agreeing with Lord Atkin to form the majority for his famous judgment on the law of negligence. If Lord Denning himself has a rival for the title of our greatest judge in that century, it might be Scotland's Lord Reid. ${ }^{44}$

In sum, Lord Denning's sparkling lecture shows that we have had at least three hundred years of Scottish judges developing and illuminating English law. It is therefore perplexing that there is such outrage at Scottish

39 See Lord Neuberger, Lord Erskine and Trial by Jury, 2012, https://www.supremecourt.uk/docs/speech-121018.pdf

40 Denning (n 5) 32.

${ }^{41}$ Denning (n 5) 32.

${ }^{42}$ Rylands v Fletcher (1865) LR 1, Ex 265, LR3 HL 330.

${ }^{43}$ Denning (n 5) 35, commenting on Donoghue v Stevenson 1932 AC 562. See Alan Rodger, 'Lord Macmillan's Speech in Donoghue v Stevenson' (1992) 108 LQR 236.

${ }^{44}$ Alan Paterson, The Law Lords (Macmillan 1982). See also Louis BlomCooper, 'The European Convention in an International Legal Setting' [1997] EHRLR 508. 
law-makers in Parliament continuing to exercise the practice of three centuries in voting on the outcome of laws confined to England or to England and Wales. Unless, that is, there is something wholly different about judicial and elected law-making. But if there is and it remains acceptable for Scots to make judicial decisions in English law, then it is not so obvious why it would be so wrong for non-English judges elsewhere in Europe to offer their insights into human rights in the legal system of England and Wales.

Whatever the explanations might be, the fact remains that Scottish judges have long since made invaluable contributions to the law south of the border. The quintessential English judge, Lord Denning, spotted this and used his famous story-telling powers to give a lecture that is in a class of its own.

The lecture is not beyond criticism. Its last two sentences ${ }^{45}$ jump to a conclusion that is not justified by the argument. In expressing the hope that the two legal systems might eventually become one, Lord Denning undid some of his good work in recounting the history of Scots lawyers rising to high judicial office south of the border. On the contrary, an attraction of the lecture and of the Union is the value of diversity, of constitutional laboratories within one state. ${ }^{46}$ Overall, however, this is a first class lecture which still has the power to surprise lawyers who do not know the biographies of famous judges of earlier centuries. Omitting the second part of the penultimate sentence and the whole of the final sentence, it would have reached this resounding conclusion, saying of Lord Kilmuir (who was then the Lord Chancellor and had previously been central to the drafting of the European Convention) ${ }^{47}$ that, "He is the latest of the many men of high principle and great endeavour who have come from Scotland to England and have enriched the law of these Islands. This process is much to be encouraged - England borrowing men and principles from Scotland for the benefit of both". ${ }^{48}$ Who knows whether this lecture in May 1961 had any effect on Lord Kilmuir's recommendation less than a year later that Lord Denning should become the Master of the Rolls? More importantly, does the thrust of this lecture have an application in our own time? To this we shall return after the main

\footnotetext{
${ }^{45}$ Denning (n 5) 39-40.

${ }^{46}$ Smith Commission https://www.smith-commission.scot/.

${ }^{47}$ Neil Duxbury, Lord Kilmuir: A Vignette (Hart 2015).

48 Denning (n 5) 39. Lord Denning was speaking at a time when it was not customary to say men and women and when there had not been a woman appellate judge in either legal system. We still await the first woman Supreme Court Justice from Scotland.
} 
body of this article looks at the ramifications of a rare Court of Appeal decision citing Magna Carta.

\section{THEY COME OVER HERE ... (PART TWO)}

In $R v$ Home Secretary, ex $p$ Phansopkar, ${ }^{49}$ a strong Court of Appeal ordered the Home Secretary to consider immigration claims in accordance with Magna Carta.

The three judges in the Court of Appeal were three of the most wellknown members of the judiciary. Despite the "Kilmuir Rules", named after the afore-mentioned Scottish Lord Chancellor who feared that too frequent appearances in the media by judges posed difficulties for their independence, Lord Denning, Sir Frederick Lawton and Sir Leslie Scarman revelled in their extra-judicial engagements in the public square. Six months before this case, in December 1974, Sir Leslie Scarman had given his famous Hamlyn Lectures on English Law - The New Dimension. $^{50}$ In February 1975, one of Sir Frederick Lawton's former pupils became leader of the Conservative Party. Margaret Thatcher went on to praise her pupil-master for his robust approach to the law, especially sentencing. ${ }^{51}$ In fact, Lord Justice Lawton's views on sentencing were nuanced. He did believe in long sentences for crimes of violence. But he is also credited for popularising the phrase "short, sharp shock" for lesser offences. The phrase comes from Gilbert \& Sullivan, The Mikado, but it was given a boost by Sir Frederick Lawton who liked to say that he had spent longer in prison than most hardened criminals, having grown up in prison as his father was a prison governor. ${ }^{52}$ The Court was not stacked for or against the government of the day. Lord Justice Lawton had been a candidate for a controversial right-wing party in his youth, having earlier flirted with the extreme Left, but Lord Justice Scarman was widely regarded as one of the most liberal of our judges. Although the Left used Lord Justice Lawton's past right-wing politics to suggest that the judiciary might be biased against those less privileged in society, ${ }^{53}$ in this case all

\footnotetext{
${ }^{49}$ Phansopkar (n 6).

${ }^{50}$ Sir Leslie Scarman, English Law - The New Dimension (Hamlyn Lectures, 26th Series 1975).

51 Margaret Thatcher commenting on Sir Frederick Lawton http://www.margaretthatcher.org/document/107570.

${ }^{52}$ Lawton - see obituaries

http://www.telegraph.co.uk/news/obituaries/1321260/Sir-Frederick-Lawton.html. http://www.theguardian.com/news/2001/feb/05/guardianobituaries1.

${ }^{53}$ Paul Foot https://www.marxists.org/archive/foot-paul/1978/04/judges.htm.
} 
three judges ruled in favour of vulnerable individuals seeking a ruling from the Home Secretary.

Two appeals were heard together by the Court of Appeal on 30 June and 1 July against the Home Secretary, ex parte Phansopkar and ex parte Begum, usually reported as $R v$ Home Secretary, ex $p$ Phansopkar. Lord Widgery, sitting with Ashworth and May JJ, dismissed the case at first instance on 24 April but Phansopkar won on appeal. Lord Widgery, sitting this time with Bridge \& Stocker JJ had then decided on May 22 that Begum was indistinguishable from Phansopkar. Although the appellate judges were not convinced there was a way of distinguishing the two cases, both were held by the Court of Appeal to be wrong on their merits. In the conjoined appeals, Lord Denning sitting as the Master of the Rolls, Lord Justice Lawton and Lord Justice Scarman all relied on Magna Carta. The timing of this case is also of interest in the light of the new Westminster government's promise of a second referendum on membership of the European Union before the end of 2017. The Phansopkar case came as that first referendum on staying in the European Community was being held in the summer of 1975. The Labour government was at the same time steering a bill through parliament to strengthen protection against sex discrimination. It was soon to do the same against race discrimination, extending the power or its pioneering 1965 and 1968 Acts.. Its Home Secretary was Roy Jenkins. His special adviser was Anthony Lester QC. The Home Office's barrister in the Court of Appeal was Harry Woolf. It would be difficult to find three more celebrated characters in our modern history of protecting and promoting human rights. Yet the Home Office at the time of what could be described as its greatest glory in terms of progressive legislation was arguing that it was entitled to send Mrs Phansopkar and Mrs Begum back to India and Bangladesh respectively and it was the judges who ordered the Labour government to resolve the matter here in the UK.

This case is too often ignored or overlooked or under-played. It is not mentioned in any of the Supreme Court Justices' Magna Carta lectures. In his leading judgment in $M,{ }^{54}$ Lord Woolf only refers to Phansopkar for a passing point (on which he gives the impression that it was a ruling requiring an immigration officer to consider the matter whereas the order of mandamus required the Home Secretary to make a decision). Ten days before the $800^{\text {th }}$ anniversary however, it does receive a passing mention from Mrs Justice Patterson in her ruling that the government had delayed

\footnotetext{
${ }^{54}$ Mv Home Office, [1994] 1 AC 377. http://www.bailii.org/uk/cases/UKHL/1993/5.html.
} 
unduly in providing disability benefit for $\mathrm{C}$ and $\mathrm{W}^{55}$. She notes that the case was cited but seems to take it as settled law, conceded by the defendants, that unreasonable delay is unlawful and so does not need to consider the detail of the case law. This is a pity because she later goes on to reject the Human Rights Act arguments that human rights have been breached. Lord Justice Lawton in Phansopkar, however, was clear that fundamental human rights were at stake with corresponding duties and that those duties not to delay the vindication of rights were imposed on the executive by Magna Carta. ${ }^{56}$

Where the case is mentioned in the academic literature, it is usually for Lord Scarman's reference to the European Convention, bolstered by the Magna Carta argument, even though Lord Denning MR and Lawton LJ did not rely on the European Convention whereas all three did invoke Magna Carta. Adam Tomkins thinks the Magna Carta references are merely obiter dicta. ${ }^{57}$ A more expansive or inclusive understanding of the ratio is, I would submit, more in keeping with the tenor of the judgments. Magna Carta was an "aid to determining the issues in the case". After all, five different judges at first instance (Lord Widgery CJ sitting in both cases) had ruled against Mrs Phansopkar and Mrs Begum by looking at the statute and Rules without contemplating Magna Carta. Lord Widgery $\mathrm{CJ}$, with whom the other judges agreed, did consider that the Act and Rules should be read subject to a common law duty but in his judgment that duty was to be fair between families queuing. It is because the three judges in the Court of Appeal recalled a prior duty under Magna Carta not to delay justice that they saw the matter differently. When in doubt about how general the level should be at which to cast the ratio of a case, we should let the judgments speak for themselves.

${ }^{55} \mathrm{C} \mathrm{W}$, disability case

http://www.bailii.org/ew/cases/EWHC/Admin/2015/1607.html.

${ }^{56}$ Phansopkar (n 6) 23.

57 A Tomkins, 'Magna Carta, Crown and Colonies' [2001] PL 571: Magna Carta was cited by all three judges of the Court of Appeal not as an aid to determining the issues in the case, but as obiter. Lord Denning MR explained that the Immigration Act 1971, section 3(9) provided that wives of patrials could enter the United Kingdom by right, rather than by leave, and as such enjoyed an entitlement, and not a mere privilege. "Such being her right," Lord Denning continued, "I do not think it can be taken away by arbitrarily refusing her a certificate, or by delaying to issue it to her without good cause". His Lordship then added that in such an event, the woman concerned could "invoke" Magna Carta. Lawton LJ agreed, stating that the Secretary of State "cannot refuse to consider the application, nor can he delay consideration unreasonably. These duties were imposed on the Crown and its servants by Magna Carta". 
It is especially important to reconsider Phansopkar fully in Magna Carta's $800^{\text {th }}$ anniversary year in case the Conservative government really does do anything approaching its manifesto pledge to "scrap" the Human Rights Act.

The facts of Phansopkar show that the strength of both Magna Carta and an "external" perspective on human rights can act as an effective check on a well-intentioned government. The Prime Minister gives the impression of being furious with European Court of Human Rights judges for deciding in favour of prisoners and those suspected of terrorism, against the wishes of what he regards as well-intentioned governments of different political complexions focusing on the common good in an era of dangerous threats to security. ${ }^{58}$

Why has the case been neglected $?^{59}$ It might be that those pressing for incorporation of the European Convention on Human Rights were embarrassed by the facts of the case. Or it could be that obscurity was caused by the headnote writers who did not include Magna Carta in their rendering of the holding. ${ }^{60}$ Or it might have slipped under the radar because it was difficult for judges sitting alongside Lord Denning to get much attention for what they said. Lawton LJ and Scarman LJ used the term "Magna Carta" but Lord Denning, Master of the Rolls, who had something of a grudge against Latin or at least against those who thought he had not mastered it or its pronunciation, called it the Great Charter. ${ }^{61}$ Or it might be that immigration laws, rules and practices changed so frequently that the significance of the broader issues was lost. Or it could have been merely that there were so many cases to choose from in the mid-1970s that custom settled on such later gems from 1975 and 1976 as Congreve $^{62}$ or Laker $^{63}$ or Tameside, ${ }^{64}$ based on popular media coverage.

58 For David Cameron's views, see eg http://www.bbc.co.uk/news/uk-politics28339263.

${ }^{59}$ For articles which do refer to the case, see eg Tomkins n 58, Anthony Lester and Jeffrey Jowell, 'Beyond Wednesbury: Substantive Principles of Administrative Law' [1987] PL 368, Michael Beloff and Helen Mountfield, 'Unconventional Behaviour? Judicial Uses of the European Convention in England and Wales' [1996] EHRLR 467, Blom-Cooper (n 44), Lord Irvine, 'The Spirit of Magna Carta Continues to Resonate in Modern Law' (2003) 119 LQR 227.

${ }^{60}$ Phansopkar (n 6) 607.

${ }^{61}$ Ibid. Although at 617 'civis angliae sum.'

${ }^{62}$ Congreve v Home Office [1976] 1 QB 629 follows Phansopkar in the official law reports of 1976 but happened in November and December of 1975, after Phansopkar in June and July 1975, in the Court of Appeal. 
Avoiding an increase in TV licence fees, liberalising trans-Atlantic travel and facilitating or inhibiting (depending on one's view) school selection played better than vindicating rights of immigrants. Another way of putting that, however, is that immigration, mental health and other spheres where Magna Carta has been applied are Cinderella subjects. This is where fundamental ${ }^{65}$ constitutional provisions are especially valuable and where innovative argument might be needed. No cases were cited in argument or judgment in Phansopkar at first instance. Counsel understood the issues of rights under threat and of the rule of law. These Cinderella subjects are going to the ball much more in the Supreme Court era than in the time of the Judicial Committee of the House of Lords, partly because of the Human Rights Act 1998 and the surrounding culture.

For whatever reason, when Ronald Dworkin had the whole of English or UK law from which to choose a case, he opted for a decision later in the same year by one of the same judges at first instance, Lord Widgery, in the Crossman Diaries case. ${ }^{66} \mathrm{He}$ seemed to think that was decided in the House of Lords. Imagine if he had instead chosen $R v$ Home Secretary, ex $p$ Phansopkar, where there was a striking difference between the approach of Lord Widgery and the Court of Appeal. Apart from anything else, other scholars might also have paid more attention to this case if it had become subject to Dworkin's sweeping jurisprudential analysis.

The substance of the disagreement between the Court of Appeal and the government on what is fair and reasonable could be put in terms of that ultimate British value of refraining from queue-jumping. In a learned article on queue-jumping, ${ }^{67}$ the property lawyer and property law theorist, Professor Kevin Gray, does not address Phansopkar. Those, like myself, who prefer the judgments of the Court of Appeal to the convenience of the Home Office might prefer a different term, and underlying British value, to queue-jumping, such as "taking the initiative" or "taking the matter into one's own hands" when faced with excessive bureaucratic delays.

Sibghatullah Kadri appeared for Mrs Phansopkar, Harry Woolf for the respondents at first instance, Sibghatullah Kadri and Anthony Eton for Mrs Phansopkar, Eugene Cotran for Mrs Begum on appeal, Harry Woolf

${ }^{63}$ Laker v Department of Trade [1977] QB 643.

${ }^{64}$ Secretary of State for Education v Tameside [1977] AC 1077.

${ }^{65}$ See eg Laws LJ Thorburn v Sunderland City Council [2003] QB 151.

${ }^{66}$ Ronald Dworkin, eg Law's Empire (Harvard University Press 1988), criticised by S Lee, 'Law's British Empire?' (1988) 8(2) OJLS 278.

${ }^{67}$ Kevin Gray

http://www.lse.ac.uk/collections/law/projects/techniquesofownership/techgray.pdf. 
for the respondents. No cases were cited at first instance and only two in the Court of Appeal, $R v$ Northumberland Compensation Tribunal ${ }^{68}$ (where Denning LJ sat as only the second senior judge) and $R v$ Home Secretary, ex $p$ Mughal, $^{69}$ where S Kadri appeared before Denning MR and Scarman LJ, that time sitting with Megaw LJ, and where Gordon Slynn was for the government. In that case, Lord Denning drew a sharp distinction between the circumstances of Mr Mughal and of a "patrial".

Lord Widgery CJ, with whom Ashworth \& May JJ agreed, explained that, "The Home Office came into this matter at quite an early stage because reference was made to them by a member of Parliament who was interesting himself in the situation of Mr Phansopkar and his alleged wife" and rejected the applications because "it must be remembered that being fair is not simply being fair to one family. It is a question of being fair to all those who suffer from this problem, and the Home Secretary is entitled in my judgment to take the view that in order to be fair to all he should not allow one family, or one individual, to obtain priority in the queue by such means as are put forward in this case." 70

As always, Lord Denning MR set out the facts and legal background in a compelling fashion:

The husband, Allimiya Bawa Phansopkar, was born in India ... He has produced a marriage certificate issued in India which shows that in 1962, when he was 27, he married his wife, Maimuna, who was then 20. The marriage was solemnised at the bride's house by her father, in accordance with the Moslem religion. Their first child, a girl, was born in January 1964. Two years later, in 1966, the husband came to England and found work here; but he went back to India from time to time to join his wife, and they had there three more children, all boys, born in May 1968, September 1971 and February 1974. Then in March 1974 the husband took a most important step. He became a citizen of this country; or, more accurately, a citizen of the United Kingdom and colonies...He himself thenceforward had "the right of abode in the United Kingdom". His right was equal to the right of abode of any of us. You and I and our families have been born here and lived here from time immemorial. Yet Mr Phansopkar, from the moment he was registered, had just as much right here as we have. He became a citizen of no mean country. He could say proudly -- if he spoke

\footnotetext{
${ }^{68}[1952] 1 \mathrm{~KB} 338$.

${ }^{69}$ [1974] QB 313.

${ }^{70}$ Phansopkar (n 6) 610.
} 
Latin -- civis angliae sum. He became a patrial. And not only he. His wife also obtained at that very moment the selfsame right... she was a Commonwealth citizen. And, as such, as soon as her husband, by registration, gained the right of abode in the United Kingdom, she acquired the selfsame right of abode ... "free to live in, and to come and go into and from, the United Kingdom without let or hindrance." 71

Yet when the Phansopkars tired of waiting in India, where the queue was long, and took action by flying to Heathrow, Mrs Phansopkar and the children were refused entry. The immigration officer required them to go back to India to secure a certificate of patriality. This made sense to the three judges at first instance but not to the three judges in the Court of Appeal. Lord Denning continued from his account of her right: ${ }^{72}$

Such being her right, I do not think it can be taken away by arbitrarily refusing her a certificate, or by delaying to issue it to her without good cause. She can invoke the Great Charter: "To none will we sell: to no one will we delay or deny right or justice." It seems to me to be implicit in this legislation that a wife, who is truly a wife, is entitled to apply for a certificate of patriality and to have her application examined fairly and in a reasonable time.

The Home Office gave no reason except that "it is considered that [the] application can be most satisfactorily dealt with by the entry certificate officer at the British High Commission in" Bombay or Dacca respectively. Lord Denning asked, "Was that a sufficient reason?" and answered no because ${ }^{73}$

a wife who applies in Bombay or Dacca for a certificate of patriality has to join a long queue of those who require leave to enter. By the time she is granted an interview, 14 months or more will have passed. The delay was so long that these two ladies, at any rate, determined to test the matter by coming here and applying here. In the circumstances I think they were justified in so doing."

\footnotetext{
${ }^{71}$ Ibid 616-7.

72 Ibid 621.

${ }^{73}$ Ibid 621-2.
} 


\section{Lord Denning therefore ordered that, ${ }^{74}$}

The Home Secretary ought not to send these ladies back to India and Bangladesh to face the long delays. He ought to examine the applications to see whether or not each lady is a patrial, and to give or refuse a certificate according to whether she satisfies him, or not.

Lawton LJ began by declaring in forthright terms the point that a right was at stake and that the Home Secretary was under a duty dating back to Magna Carta: ${ }^{75}$

These appeals concern rights, not privilege. The rights are fundamental human rights -- of husbands and wives to live together." The Home Secretary "cannot refuse to consider the application; nor can he delay consideration unreasonably. These duties were imposed on the Crown and its servants by Magna Carta ... Administrative convenience, however well intentioned it may have been, cannot be made a justification for depriving people of their rights or for delaying consideration of their claims to rights... I would allow the appeal and order that the Secretary of State for Home Affairs shall consider and determine the applications for certificates of patriality made by both these appellants.

Scarman LJ also took the matter seriously as a breach of rights which could be traced back to a "hallowed principle of our law" "76 in Magna Carta, now reinforced by the European Convention: ${ }^{.7}$

The background to these two appeals is disturbing. We have been told by counsel for the Secretary of State that in 1974, 12,864 entry certificates were granted by overseas offices in the Indian sub-continent and 859 certificates of patriality. It is significant that during the year not one application for a certificate of patriality was refused, though the applicants had to endure the wait in the queue for 14 months or more... Delay of this order appears to me to infringe at least two human rights recognised, and therefore

\footnotetext{
${ }^{74}$ Ibid 623.

75 Ibid 623.

76 Ibid 626.

77 Ibid 625 .
} 
protected, by English law. Justice delayed is justice denied: "We will not deny or defer to any man either justice or right": Magna Carta. This hallowed principle of our law is now reinforced by the European Convention for the Protection of Human Rights 1950 to which it is now the duty of our public authorities in administering the law, including the Immigration Act 1971, and of our courts in interpreting and applying the law, including the Act, to have regard: see R v Secretary of State for Home Affairs, ex parte Bhajan Singh in this court... It may, of course, happen under our law that the basic rights to justice undeferred and to respect for family and private life have to yield to express requirements of a statute. But in my judgment it is the duty of the courts, so long as they do not defy or disregard clear unequivocal provision, to construe statutes in a manner which promotes, not endangers, those rights. Problems of ambiguity or omission, if they arise under the language of an Act, should be resolved so as to give effect to, or at the very least so as not to derogate from, the rights recognised by Magna Carta and the European convention.

Leave to appeal to the House of Lords was granted but no appeal was pursued. The ratio of the case could be put at various levels of generality. All three judges, however, framed the case in terms of Magna Carta, both because of its longevity and because of its fundamental nature. All three interpreted the common law as reading into the Immigration Act and Rules that the Home Secretary's actions are subject to Magna Carta, now for Lord Justice Scarman reinforced by the European Convention. Scarman LJ accepts that express provision in a statute could restrict the reach of Magna Carta and the Convention. It might have been thought implausible, however, that a political party would want to push through Parliament legislation which spelled out that its ministers were to have an exemption from Magna Carta. It is now just about possible that the current government has in mind the equivalent of "Notwithstanding any provision to the contrary in the Human Rights Act" but restricting the ambit of a statute of 17 years is not comparable to acting contrary to Magna Carta's 800 years of imposing duties on those in government. But he is clear that without an express counter, the statute must be construed so as to conform to duties under Magna Carta.

The facts of Phansopkar are most relevant to that contentious issue in contemporary politics of immigration, even though the significance of the case goes way beyond this context in speaking to us today. Commentators who might describe themselves as liberal- or Left-leaning criticise Conservative ministers and media for seeking to demonise immigrants 
and to deter or at least delay their entry into the UK. In its broadest application, the case has been cited in the very month of Magna Carta's $800^{\text {th }}$ anniversary by Mrs Justice Patterson in a ruling on unreasonable delays in disability benefits. Phansopkar itself, however, was a decision in favour of women from India and Bangladesh against a Labour government which prided itself on its attitudes to equality on grounds of race and gender.

Indeed, it is worth recalling that three legendary figures in our human rights history were, in a sense, on the losing side of this case. Roy Jenkins was the Home Secretary held to be in breach of Magna Carta, Anthony Lester QC was his special adviser (although I do not mean to suggest that he would have advised on individual cases) and Harry Woolf was the counsel for the Home Office, trying to defend the Labour government's attempt to send Mrs Phansopkar and Mrs Begum back to queues in India and Bangladesh respectively, rather than resolve their claims where they were. I say "in a sense" because no doubt the special adviser was busy drafting the famous laws against race and sex discrimination and was unaware of the Phansopkar case. Likewise, Harry Woolf was briefed to argue for the Home Office, not to offer his own opinion on the merits of this particular immigration claim. It may even be that Roy Jenkins was too busy on policy questions to focus on the legal or political ramifications of his great department of state seeking to deport Mrs Phansopkar. In any event, the Home Office was roundly defeated on appeal.

Lord Justice Scarman had some sympathy for the Home Secretary: "One final word. This is not a case of an unthinking, heartless exercise of administrative power. The Secretary of State is clearly, and rightly, troubled by that queue." ${ }^{, 78}$ This aspect of Phansopkar is worth belabouring (be-Labouring) because it shows that with the best of intentions, a government which prides itself on human rights can be held to have erred. The current debate is as if the Conservative government's self-proclaimed good intentions of, for example, protecting national security are enough to render otiose recourse elsewhere. But Phansopkar shows that this is not so. Turning this the other way round, when a government is defeated on such grounds, perhaps opponents should not crow so much as if the government was therefore acting in bad faith. Perhaps this is the root of Conservative dissatisfaction with being upbraided by European or domestic judges.

So what became of some of the principal characters involved in this litigation? The Home Secretary soon became President of the European Commission and later Lord Jenkins of Hillhead. Anthony Lester became

\footnotetext{
${ }^{78}$ Ibid 628-9.
} 
Lord Lester, much involved in the movement to incorporate the European Convention into British law. Harry Woolf became Lord Woolf, Master of the Rolls and then Lord Chief Justice.

It is clear from the official law reports that counsel for Mrs Phansopkar raised the issue of the European Convention and a claim of habeas corpus but the reports are silent on whether counsel themselves invoked Magna Carta. Counsel for the Home Secretary responded to the Convention point in raised by counsel for Mrs Begum so presumably would have replied on Magna Carta if that had been raised explicitly. Whether counsel invoked Magna Carta or whether the formidable Bench saw the point was implicit in initial arguments, Sibghat (or Sibgatullah or Sib) Kadri and Eugene Cotran deserve credit for winning their cases and for the way in which they were won, with a so far unfulfilled potential to safeguard fundamental rights. Just as the stream of judges from Scotland have brought refreshingly different perspectives to English law, counsel for Mrs Phansopkar had the distinctive experience of having himself been detained without trial, contrary to Magna Carta, in another part of the Commonwealth. Both counsel for Mrs Phansopkar and for Mrs Begum knew what it was to come to the UK from a troubled part of the world. Even if they did not invoke Magna Carta explicitly, they might well have led the judges to think of it for themselves.

Sibghat Kadri ${ }^{79}$ was born in India in 1937, migrating to Pakistan soon after partition in 1947. He was active in student politics at Karachi University where he was arrested and imprisoned without trial for opposing the military regime in 1958. He drafted his own petition for habeas corpus and secured his own release but was deported to Hyderabad in 1959. He came to England in 1960. He remained active in Pakistan politics in England and worked for the BBC as a producer and broadcaster in Urdu and in English. He was called to the Bar in 1969. After pupillage, he formed his own set of chambers and then, with Rudy Narayan the Afro-Asian and Caribbean Law Association which became the Society of Black Lawyers. He became Queen's Counsel in 1989 and a Bencher of the Inner Temple in 1997. Over decades he has consistently challenged discriminatory practices and comments in the legal profession, saying that, "Even Lord Denning, as brilliant as he was then, was not colour blind", and later successfully calling for Lord Denning's resignation over the publication of his book criticising jurors in the Bristol riot case.

${ }^{79}$ http://www.onlinebld.com/lawyer_of_the_month/sibghatkadriqc.html. 
Eugene Cotran ${ }^{80}$ the lawyer for the other appellant, Mrs Begum, had been born in Jerusalem. He was a refugee who went to school in Alexandria and then studied law at the universities of Leeds and Cambridge. He was stateless before becoming a British citizen. After working in academe and legal practice in London, he became a High Court judge in Kenya before returning to the UK to practise as a barrister and to resume academic work at SOAS. He became the first Arab and Palestinian circuit judge. He was a Greek Orthodox Christian who had a lifelong interest in the law surrounding the Palestinian cause, including a prominent role in drafting its Basic Law. He died in the summer of 2014. The law report's summary of his argument before the Court of Appeal suggests that he had convinced Lord Justice Lawton who began his judgment in strikingly similar terms, that the cases concerned a right, not a privilege.

One of the Phansopkar children, Nawaz, his wife and their children fled their flat above a grocer's shop when it was being destroyed by fire during the Croydon riots of $2011 .{ }^{81}$ Indeed, it was press coverage of this tragedy, linking the name of Phansopkar and the location of Croydon (where Mr \& Mrs Phansopkar went through an English marriage ceremony, for the avoidance of doubt, before the hearing), which led to me recalling this case. ${ }^{82}$

\section{WHAT SAY THE REEDS AT RUNNYMEDE?}

Is there any link between the lecture on Borrowing from Scotland and this case applying Magna Carta? My contention is that there is a common element. It is a culture of magnanimity, of big-heartedness and openness towards different ways of looking at the law and society, sometimes from the past, sometimes from current circumstances, sometimes from afar, sometimes from nearby.

\footnotetext{
${ }^{80} \mathrm{http}: / /$ archive.thisweekinpalestine.com/details.php?id=2327\&ed=148\&edid=14 8 (accessed 9 June 2015) https://archive.is/mkUM1 (accessed 10 June 2015).

81 Croydon http://www.telegraph.co.uk/news/uknews/crime/8699765/Countingthe-cost-of-the-riots-the-street-where-looters-caused-14m-damage-in-12hours.html.

${ }^{82}$ The connection can be traced by looking at a mapping exercise of India, which lists names associated with a property as in a private census: the eldest generation have the names of the litigants in Phansopkar, Nawaz is the second child, one of the daughters-in-law matches (with a slight variation in spelling in English) the name of his wife Hayatbi, and four of the grandchildren have the names of those burned out of the flat in Croydon http://wikimapia.org/1500679/Al-Bawa-House
} 
Louis Blom-Cooper ${ }^{83}$ speculated on what might have been if the Scottish law lord, Lord Reid, whom he described as "the greatest judge of our times" had lived a little longer and if Phansopkar and two other cases from the Court of Appeal had gone on appeal to the Judicial Committee of the House of Lords: "One can surmise that, had Lord Reid been given the opportunity to consider the jurisprudence developing in the Court of Appeal in and around 1975/1976, he would have affirmed the trilogy of 1975 cases $^{84}$ and applied international legal norms ... (Lord Reid retired on January 10, 1975 and died on March 29, 1975.)"

One of our current Supreme Court Justices from Scotland, Lord Reed, has given a most insightful lecture ${ }^{85}$ on domestic legal systems and the European Convention on Human Rights, pointing out that France and Germany do not have the same exaggerated deference to Strasbourg decisions as has been implied in the British constitutional debate. He has argued for the resilience and ingenuity of the common law in finding imaginative ways to develop itself rather than simply deferring to Strasbourg, pointing out that this is necessary if we are to continue to offer a good example to the rest of the world in respecting the rule of law. This could be said to be a fall-back position in case the Human Rights Act is scrapped and nothing much replaces it on the statute book. More positively, it can be taken at face value as endorsing the approach adopted in Phansopkar (although again this case is not cited).

Many of the lawyers who have argued or decided human rights cases have come from different legal and political systems, such as Sydney Kentridge QC, Lord Hoffmann and Lord Steyn from South Africa. ${ }^{86}$ The Hong Kong final court has even built this into its practice by including a wide range of judges from outside its own legal system. The experiences and courage of Sibghat Kadri and Eugene Cotran deserve a place in this company. In the case of Mr Kadri, for example, he showed ingenuity before he even studied law in securing his own release under martial law through habeas corpus. In Phansopkar, he called the Home Office to account, thanks to the Master of the Rolls and colleagues applying Magna Carta, and then later he called the Master of the Rolls himself to account.

\footnotetext{
${ }^{83}$ Blom-Cooper (n 44).

${ }^{84}$ Phansopkar, Birdi v Home Secretary [1975] SJ 322, $R$ v Home Secretary, ex $p$ Bhajan Singh [1976] QB 198.
}

${ }^{85}$ Lord

Reed http://www.innertemple.org.uk/downloads/members/lectures_2013/lecture_reed_ 2013.pdf.

${ }^{86}$ See eg Sydney Kentridge, Free Country (Hart 2012) or 'Desert Island Discs' http://www.bbc.co.uk/programmes/b01rl0z9. 
As for Eugene Cotran, he saw himself as a Palestinian refugee and went on to be a judge in two legal systems in two continents, in Kenya and in England. His father Michel Cotran, incidentally, had the same distinction, having been Chief Registrar of the Judiciary in Jerusalem under the British Mandate, then becoming a refugee in Egypt before becoming a judge in Nigeria and then Chief Justice of West Cameroon. ${ }^{87}$

This is not to say there is no merit in English votes for English laws in the different law-making realm of elected politicians deciding on statutes. But neither is it especially Conservative to ignore a long history of insights from across the Border. Borrowing from Scotland points us in the direction of magnanimity and wisdom in continuing to draw on Scottish judges, even if a more federal UK is the answer to the West Lothian question or even if Scotland were to become independent. The UK Supreme Court does not have jurisdiction in Scottish criminal law, unless there are human rights arguments, in which case the Scottish judges will be in a minority.

Lord Denning ended his article in The Times on Magna Carta's $750^{\text {th }}$ anniversary with a quotation from Rudyard Kipling's poem, What Say the Reeds at Runnymede? ${ }^{88}$ Although prone to go beyond the bare facts to give some colour to a case, none of the judges in Phansopkar mentioned how close the scene of the immigration officers' refusals was to Runnymede, where Magna Carta was sealed in 1215 . Heathrow is only a few miles away.

Lord Reed is yet to turn his attention to Magna Carta but for these purposes the Reeds (to include the Reids) are those judges with experience of another legal system in these islands ${ }^{89}$ and of legal systems on the Continent or those lawyers with a similar spirit of openness to diverse influences. Borrowing from Scotland and following Phansopkar are two paths ${ }^{90}$ towards the same Holy Grail of a legal system open to different ways of challenging conventional wisdom at the behest of

\footnotetext{
${ }^{87}$ https://archive.is/mkUM1.

${ }^{88}$ Rudyard Kipling, The Reeds of Runnymede (Magna Charta, June 15, 1215).

${ }^{89}$ For a different example, see J Lee and S Lee, 'Humility in the Supreme Court' (2015) 26 King's Law Journal 165, pointing out that Lord Kerr, the lone dissenter in $R$ (on Application by Lord Carlile QC and others) v Home Secretary [2014] UKSC, has distinctive and invaluable experience of balancing rights in a legal system in conflict from his time as a barrister, judge and ultimately Lord Chief Justice of Northern Ireland.

${ }^{90}$ Lord Denning concludes his book The Discipline of Law (Butterworths 1979) thus: 'My plea is simply to keep the path to justice clear of obstructions which would impede it.' 314.
} 
fearless advocates and pioneering litigants. If we are to be no mean country, we should not imagine that the past of Magna Carta is a foreign country, especially at a time when the government is contemplating fundamental constitutional reform. The spirit of Runnymede, "The lissom reeds that give and take, That bend so far, but never break", ${ }^{91}$ can still speak to the rule of law. ${ }^{92}$ As Kipling's poem concludes:

And still when Mob or Monarch lays Too rude a hand on English ways, The whisper wakes, the shudder plays, Across the reeds at Runnymede. And Thames, that knows the moods of kings, And crowds and priests and suchlike things,

Rolls deep and dreadful as he brings Their warning down from Runnymede ${ }^{93}$

\footnotetext{
${ }^{91}$ Kipling (n 88), first stanza.

92 Bingham, The Rule of Law (Penguin 2011), especially 10-13.

93 I am grateful to an anonymous reviewer for suggesting the last stanza as arguably a better explanation of the spirit of Magna Carta because it can explain the trial of Charles I, on the one hand, and the proper use of the Public Order Act 1936 and 1986, on the other. This has the merit also of reminding us that Kipling is a more subtle and less bourgeois or jingoist poet than, eg, George Orwell credits.
} 